\title{
Influence of light on bacterioplankton production and respiration in a subtropical coral reef
}

\author{
J. D. Pakulski ${ }^{1, *, * *}$, P. Aas ${ }^{2, * *}$, W. Jeffrey ${ }^{2}$, M. Lyons ${ }^{2}$, L. Von Waasenbergen ${ }^{3}$, \\ D. Mitchell ${ }^{4}, \mathrm{R}$. Coffin ${ }^{1, * * * *}$

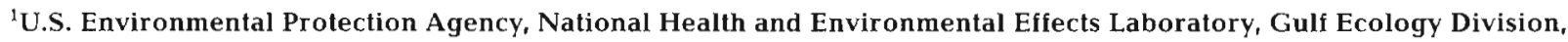 \\ Sabine Island Dr., Gulf Breeze, Florida 32561, USA \\ ${ }^{2}$ Center for Environmental Diagnostics and Bioremediation, University of West Florida, Pensacola, Florida 32514, USA \\ ${ }^{3}$ Dept of Microbiology, Oklahoma St. University, Stillwater, Oklahoma 74078, USA \\ ${ }^{4}$ M. D. Anderson Cancer Center, Smithville, Texas 78957, USA
}

\begin{abstract}
The influence of sunlight on bacterioplankton production $\left[{ }^{14} \mathrm{C}\right.$-leucine (Leu) and ${ }^{3} \mathrm{H}-$ thymidine (TdR) incorporation; changes in cell abundances] and $\mathrm{O}_{2}$ consumption was investigated in a shallow subtropical coral reef located near Key Largo, Florida, USA. Quartz (light) and opaque (dark) glass biological oxygen demand (BOD) bottles containing $0.8 \mu \mathrm{m}$ filtered reef water amended with $\mathrm{C}$, $\mathrm{N}$ and $\mathrm{P}$ were incubated in situ and exposed to natural variations in solar radiation over a $48 \mathrm{~h}$ period. Photoinhibition of Leu and TdR incorporation was observed at all depths during both daylight periods. Photoinhibition of bacterial production decreased with depth and was significantly higher during the first day of exposure. Bacterial abundances also decreased during daylight periods particularly during the second day of exposure. Leu and TdR incorporation rates and bacterial abundances exhibited recovery during periods of darkness. Light treatment bacterial $\mathrm{O}_{2}$ consumption was inhibited at all depths during Day 1 but enhanced relative to dark treatments at all depths during Day 2. Estimates of light treatment bacterial gross growth efficiencies (GGE) determined during the evening of Day 1 were similar to dark treatment estimates. Light treatment GGE determined during Day 2, however, were lower than dark treatments but increased with depth. Recovery of bacterial production and respiration during the second day of exposure suggested photoinduced selection for light tolerant cells and/or physiological adaptation to ambient light regimes occurred over the duration of exposure. The results of this experiment suggested that solar radiation may have a significant effect on bacterial metabolism in this shallow euphotic marine ecosystem.
\end{abstract}

KEY WORDS: Bacteria - Photoinhibition - Metabolism

\section{INTRODUCTION}

Bacteria are widely regarded as important components of marine ecosystems (Azam et al. 1983, Cole et al. 1988, Cho \& Azam 1990). Whereas light has long

•E-mail: pakulski@morgan.ucs.mun.ca

Present addresses:

- Ocean Sciences Centre, Memorial University of Newfoundland, Logy Bay Rd, St. John's, Newfoundland, Canada A1C 557

-. Naval Research Laboratory, Environmental Quality Sciences, 4555 Overlook Ave. SW, Washington DC 20375, USA

-..Dept of Biology, University of Minnesota-Duluth, Duluth, Minnesota 55812, USA been recognized as a factor influencing photosynthesis (Kirk 1994) and the activities of fish and zooplankton (Kampa 1976), the influence of light on the activities of non-photosynthetic aquatic bacteria has only recently been appreciated. Photoinhibition of nitrifying bacteria has been demonstrated in both the field and the laboratory (Hooper \& Terry 1974, Ward 1985, Yoshioka \& Saijo 1985, Vanzella et al. 1989, Horrigan \& Springer $1990)$ and has been invoked as a mechanism influencing the spatial distribution of $\mathrm{NH}_{4}{ }^{+}$and $\mathrm{NO}_{2}{ }^{-}$oxidization in rivers, estuaries and pelagic marine ecosystems (Olsen 1981, Lipshultz et al. 1985, Owens 1986). Exposure to solar radiation similarly influences the production and metabolism of heterotrophic bacteria directly, by photoinhibition (Bailey et al. 1983, Sieracki \& 
Sieburth 1986, Herndl, et al. 1993, Müller-Niklas et al 1995), or indirectly, through photochemical transformations of dissolved organic matter (Lindell et al. 1995 , 1996, Wetzel et al. 1995), photochemical production of toxins (Cooper et al. 1989, Vanzella et al. 1989), reduced bacteriophage viability (Wommack et al. 1996) or reduced bacterivory by heterotrophic nanoflagellates (Sommaruga et al. 1996).

Ultraviolet radiation (UVR) is primarily responsible for photoinhibition of bacterioplankton (Sieracki \& Sieburth 1986, Herndl et al. 1993, Müller-Niklas et al. 1995, Lindell et al. 1996). As global stratospheric ozone depletion is expected to enhance the flux of UV-B (280 to $320 \mathrm{~nm}$ ) to the Earth's surface (Stolarski et al. 1992), the impact of solar radiation on aquatic systems may increase in significance (Häder et al. 1995). In marine surface waters, however, UVR is rapidly attenuated with depth (Smith \& Baker 1979). The influence of UVR on deep-sea ecosystems is thus restricted to near-surface waters which may lessen its impact on bacterial metabolism integrated over the entire water column. In coral reefs and other shallow non-turbid marine ecosystems, however, UVR may penetrate through a significant portion of the water column (Fleishmann 1989). Although these shallow marine systems comprise only a small percentage of the ocean's total area, they very often possess significant economic, recreational or conservation value. Assessing the impact of solar radiation on bacterial metabolism in these systems is important to our understanding of the ecology and management of these habitats and may provide insights into the influence of solar radiation in other euphotic marine systems. In the present investigation, we evaluated the impact of in situ solar radiation on bacterial production and respiration in a Florida (USA) coral reef.

\section{METHODS AND MATERIALS}

Field studies were conducted at 'Pickles Reef' (depth at study site $\sim 4.5 \mathrm{~m}$ ) located within Key Largo National Marine Sanctuary (Key Largo, Florida, USA) during the period 1 to 5 May 1995 (Fig. 1). The portion of the reef studied was exposed to advective exchange with adjacent coastal waters. Reef water for experimental incubations was collected before dawn with a pump from a depth of $2 \mathrm{~m}$ and subsequently filtered though a $0.8 \mu \mathrm{m}$ polycarbonate cartridge filter (Nuclepore) to remove larger eucaryotic organisms. Preliminary experiments with unfiltered reef water indicated that community $\mathrm{O}_{2}$ consumption was below the limit of detection $\left(<0.03 \mu \mathrm{M} \mathrm{O}_{2} \mathrm{~h}^{-1}\right)$. To stimulate bacterial growth and $\mathrm{O}_{2}$ consumption, and to ensure that nutrients and organic substrates were not depleted over the course of the incubations, 51 of filtered reef water was
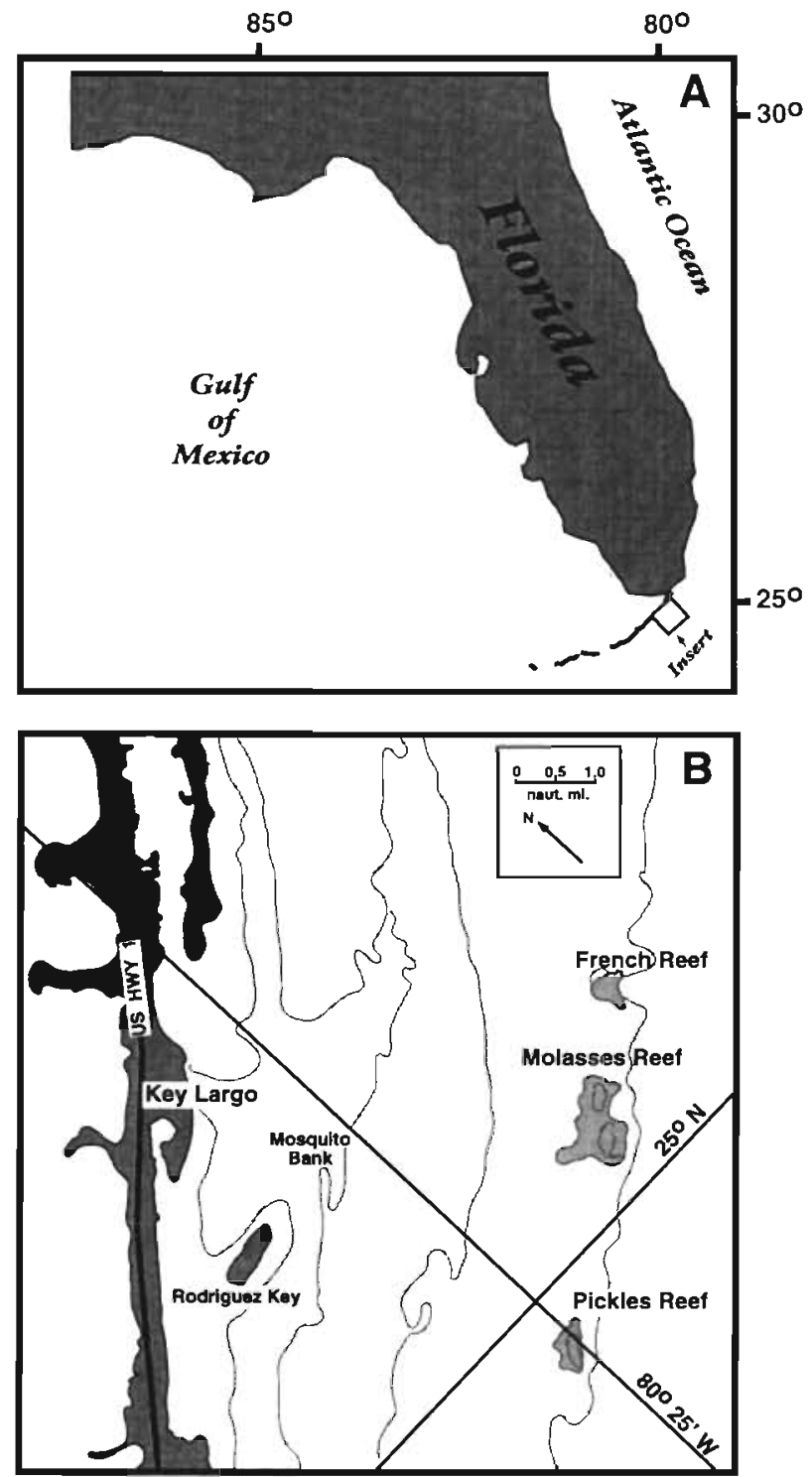

Fig. 1. Location of study site

amended with glucose, $\mathrm{NH}_{4}{ }^{+}$and $\mathrm{PO}_{4}^{-}(20 \mu \mathrm{M}$ final concentration each) and dispensed into $\mathrm{HCl}$ - and sample-rinsed $60 \mathrm{ml}$ quartz $\mathrm{BOD}$ (biological oxygen demand) bottles (light treatments; Quartz Scientific, Fairport Harbor, $\mathrm{OH}, \mathrm{USA}$ ) and $60 \mathrm{ml}$ Al-foil-covered borosilicate (dark treatments) BOD bottles. The quartz bottles were transparent to UVR and transmitted $95 \%$ of incident light (unpubl. data).

Light and dark bottles were deployed by SCUBA divers on the reef at 1.5 and $3.0 \mathrm{~m}$. Bottles were attached to floating racks anchored in the sediment. Racks were designed to remain upright under turbulent conditions. An additional set of light and dark bottles were transported to shore and incubated at a depth of $0.1 \mathrm{~m}$ in an outdoor flowing-seawater bath. Initial $\mathrm{O}_{2}$ 
concentrations and radiolabel uptake rates were determined at dawn on the first day of the experiment. Dark bottles suspended at $1.5 \mathrm{~m}$ were used as controls for both the 1.5 and $3.0 \mathrm{~m}$ light treatments. Subsequent time points were sampled at dusk ( $t=12 \mathrm{~h}$ ) on Day 1 , dawn $(t=24 \mathrm{~h})$ and dusk $(t=36 \mathrm{~h})$ of Day 2 , and at dawn $(t=48 \mathrm{~h})$ of Day 3 . Depth profiles of downwelling UV radiation $(305 \mathrm{~nm}$ ) were measured at the reef site at local solar noon during Day 1 and Day 2 with a profiling UV radiometer (Biospherical Instruments model PUV-500).

Oxygen concentrations were determined by the precision micro-Winkler method (Oudot et al. 1988, Granéli \& Granéli 1991) using a Brinkman Model 665 Dosimat autotitrator and 686 Titroprocessor. Reefdeployed bottles were fixed in the field and returned to the laboratory for titration. Changes in $\mathrm{O}_{2}$ concentrations were determined from analyses of 3 bottles sampled at each time point. Mean coefficient of variation $(\% \mathrm{CV})$ for $\mathrm{O}_{2}$ analyses was $0.27 \%$

Photosynthetic $\mathrm{O}_{2}$ production may potentially interfere with measurements of heterotrophic $\mathrm{O}_{2}$ consumption in the light. In a separate experiment, photosynthetic carbon fixation was measured in filtered reef water. Triplicate $100 \mathrm{ml}$ aliquots of unamended $0.8 \mu \mathrm{m}$ filtered reef water were dispensed into $\mathrm{HCl}$ - and sample-rinsed, light and dark (Al-foil-covered) clear plastic (polymethylpentene) $150 \mathrm{ml}$ flasks, inoculated with $5.0 \mu \mathrm{Ci} \mathrm{H}^{14} \mathrm{CO}_{3}{ }^{-}$and incubated at a depth of $0.1 \mathrm{~m}$ for $6 \mathrm{~h}$ in an outdoor flowing-seawater bath. Incubations were terminated by filtration through $0.2 \mu \mathrm{m}$ filters (Poretics). Filters were acidified and allowed to degas unincorporated label prior to scintillation counting. Potential photosynthetic $\mathrm{O}_{2}$ production was estimated from ${ }^{14} \mathrm{C}$ assimilation assuming a photosynthetic quotient $\left(\Delta \mathrm{O}_{2} / \Delta \mathrm{CO}_{2}\right)$ of 1.3

An additional set of quartz and opaque glass bottles containing nutrient-amended filtered reef water was used to measure changes in bacterial abundances and production. Bacterial production was measured by the simultaneous incorporation of ${ }^{3} \mathrm{H}-\mathrm{TdR}$ and ${ }^{14} \mathrm{C}$-Leu (Chin-Leo \& Kirchman 1988). At each time point, triplicate $5 \mathrm{ml}$ subsamples of water from a single light and dark bottle were amended with TdR $\left(84 \mathrm{mCi} \mathrm{mmol}^{-1}\right.$; $10 \mathrm{nM}$ final concentration, New England Nuclear) and Leu (324 mCi mmol-1; $20 \mathrm{nM}$ final concentration, New England Nuclear) and incubated for $30 \mathrm{~min}$ in the dark at ambient seawater temperature. Controls were poisoned with formaldehyde (2.5\% final concentration). Incubations were terminated by filtration through $0.2 \mu \mathrm{m}$ filters (Poretics). Filters were rinsed with $5 \mathrm{ml}$ of ice-cold 5\% trichloroacetic acid and $80 \%$ ethanol prior to scintillation counting. Percent photoinhibition of bacterial production was estimated by comparing light treatment rates to dark treatment rates:
$\%$ photoinhibition $=\frac{\text { light treatment production }}{\text { dark treatment production }} \times 100$

Samples for bacterial abundance estimates were obtained at each time point and fixed with Lugol's solution (Nishino 1986). Additional samples were fixed at the beginning and end of the incubations with $0.2 \mu \mathrm{m}$ filtered buffered formalin (2.5\% final concentration) to enumerate autofluorescent (photosynthetic) organisms. Bacteria were collected onto $0.2 \mu \mathrm{m}$ filters (Poretics), stained with DAPI and enumerated by epifluorescent microscopy (Porter \& Feig 1980). Because of the limited volume of the quartz flasks $(60 \mathrm{ml})$ used to determine bacterial production and abundances, only a single subsample for bacterial counts was obtained at each time point.

Bacterial production and $\mathrm{O}_{2}$ consumption rates were used to estimate community gross growth efficiencies (GGE) of heterotrophic bacteria using the formula:

$$
\mathrm{GGE}=\frac{\text { bacterial } \mathrm{C} \text { production }}{\text { bacterial } \mathrm{C} \text { production }+ \text { bacterial } \mathrm{C} \text { respiration }} \times 100
$$

Because light treatment $\mathrm{O}_{2}$ consumption during Day 1 and dark treatment $\mathrm{O}_{2}$ consumption during the evening of Day 2 were below the limit of detection (see 'Results'), GGE for light and dark treatments were determined during the first nighttime period ( $t=12$ to $t=24 \mathrm{~h})$ and Day $2(t=24$ to $t=36 \mathrm{~h})$. Mean Leu incorporation rates (average of the 2 time points within the period) and $\mathrm{O}_{2}$ consumption determined over each interval were used to estimate community GGE in both light and dark treatments at all 3 depths. Leu incorporation rates were converted to bacterial $\mathrm{C}$ production assuming a conversion factor of $3.1 \mathrm{~kg} \mathrm{C} \mathrm{mol}^{-1}$ leucine incorporated (Simon \& Azam 1989). Conversion of $\mathrm{O}_{2}$ consumption rates to $\mathrm{C}$ equivalents assumed a respiratory quotient $\left(\Delta \mathrm{CO}_{2} / \Delta \mathrm{O}_{2}\right)$ of 1 .

\section{RESULTS}

\section{Depth profiles of downwelling UV radiation}

Depth profiles of UVR indicated that samples suspended at 1.5 and $3.0 \mathrm{~m}$ were subjected to $305 \mathrm{~nm}$ irradiance at levels $>0.5 \mu \mathrm{W} \mathrm{cm} \mathrm{cm}^{-2}$ at local solar noon during both days of the experiment (Fig. 2). UVR measured during Day 1 was higher than that measured during Day 2, particularly at 1.5 and $3.0 \mathrm{~m}$.

\section{Leucine and thymidine incorporation}

In the $0.1 \mathrm{~m}$ deployment, light treatment $\mathrm{TdR}$ and Leu incorporation rates were -100 -fold lower than 
Irradiance at $305 \mathrm{~nm}\left(\mu \mathrm{W} / \mathrm{cm}^{2}\right)$

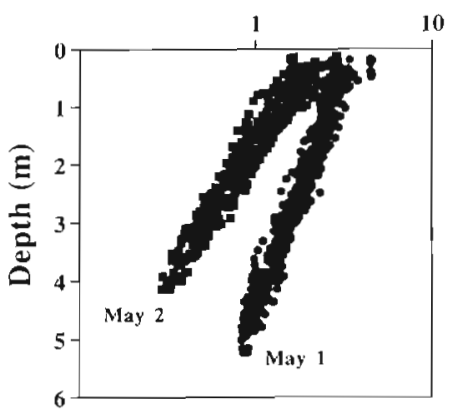

Fig. 2. Depth profiles of downwelling $305 \mathrm{~nm}$ solar radiation at the study site, May 1 and 2, 1995

dark treatment incorporation rates measured at dusk of Day 1 (Figs. $3 \& 4$ ). Light treatment Leu and TdR incorporation rates recovered to values no different ( $p>0.05$; Student's $t$-test) from dark treatments at dawn of Day 2. Light treatment TdR incorporation was significantly higher, but Leu incorporation significantly lower than dark treatments at dusk of Day 2. Light treatment TdR incorporation was not significantly different than dark TdR incorporation at dawn of Day 3. Light treatment Leu incorporation rates at dawn of Day 3, however, remained significantly lower than dark treatment Leu incorporation rates.

Light and dark treatment TdR and Leu incorporation rates in the 1.5 and $3.0 \mathrm{~m}$ deployments followed temporal patterns similar to those observed in the $0.1 \mathrm{~m}$ deployment (Figs. $3 \& 4$ ). Light treatment TdR and Leu incorporation rates were significantly lower than the dark treatments at dusk of both Day 1 and 2, but recovered to rates not significantly different than dark treatment rates at dawn of Day 2 and 3.

Percent photoinhibition of Leu and TdR incorporation measured at dusk of both daylight periods was greatest in the $0.1 \mathrm{~m}$ samples and declined with depth (Table 1). Mean percent photoinhibition of Leu incorporation was significantly $(\mathrm{p}=0.05)$ higher on Day 1 ( $77 \%$ inhibition) of the experiment compared to Day 2

Table 1 Percent photoinhibition of reef bacterial leucine (Leu) and thymidine (TdR) incorporation during exposure to solar radiation

\begin{tabular}{|lcccc|}
\hline \multirow{2}{*}{ Depth $(\mathrm{m})$} & \multicolumn{2}{c}{ Day 1 } & \multicolumn{2}{c}{ Day 2 } \\
& Leu & TdR & Leu & TdR \\
\hline 0.1 & 94 & 93 & 48 & $0^{6}$ \\
1.5 & 74 & 70 & 43 & 47 \\
3.0 & 62 & 60 & 42 & 37 \\
Mean \pm SD & $77 \pm 16$ & $75 \pm 16$ & $44 \pm 3$ & $28 \pm 25$ \\
"Light incorporation rate greater than dark rate & \\
\hline
\end{tabular}
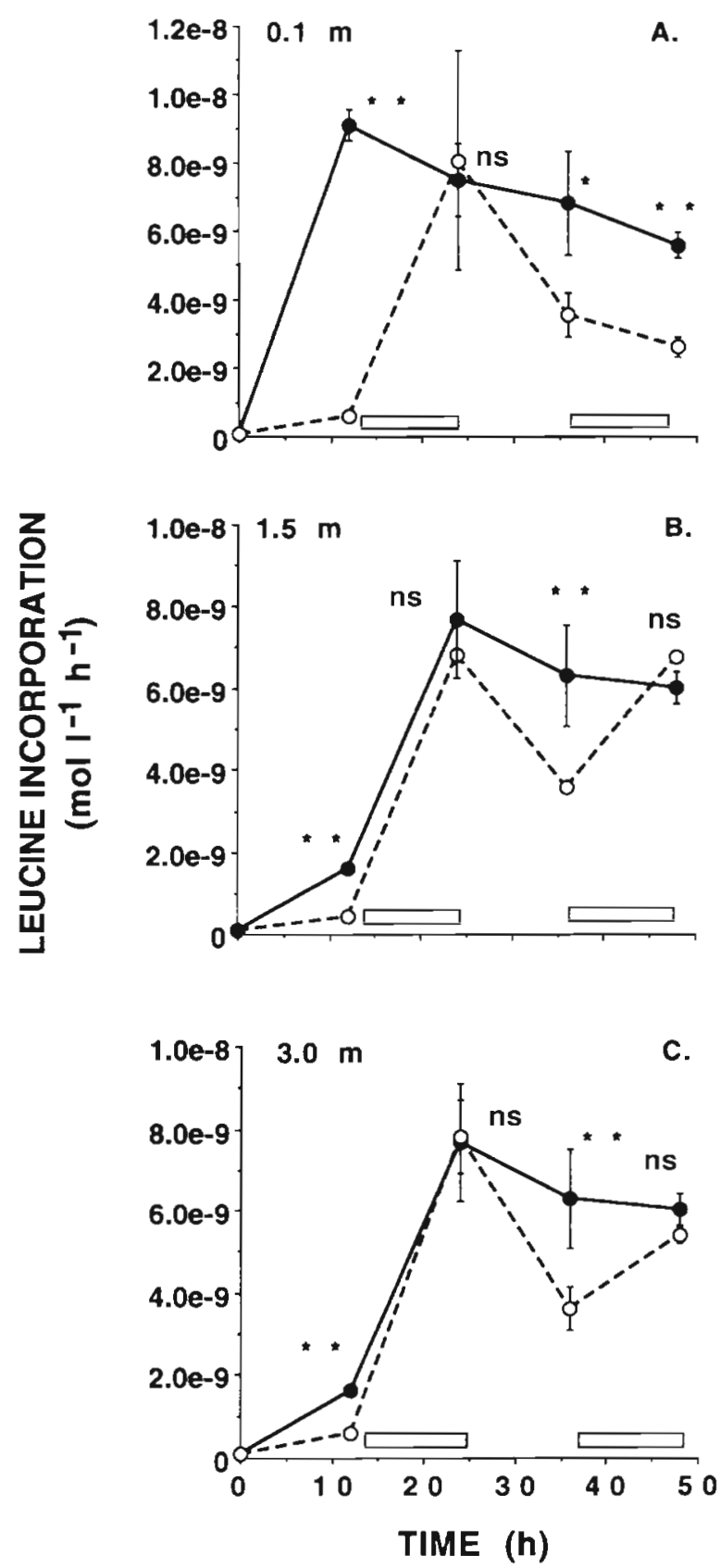

Fig. 3. Time course of bacterial leucine (Leu) incorporation rates in $0.8 \mu \mathrm{m}$ size-fractionated reef water exposed to in situ solar radiation, May 1 to 3, 1995. (O) Light treatments; (O) dark treatments. Error bars $= \pm 1 \mathrm{SD}$. Bars on $x$-axis approximate periods of darkness. Statistical differences between light and dark treatments: $" p<0.05, " p<0.10$; ns: not significant

(44\% inhibition). Percent inhibition of TdR incorporation rates was also lower on Day 2 compared with Day 1, but these differences were not significant. Differences in percent photoinhibition of Leu and TdR incorporation between Day 1 and Day 2 were also greatest at $0.1 \mathrm{~m}$ and declined with depth. 

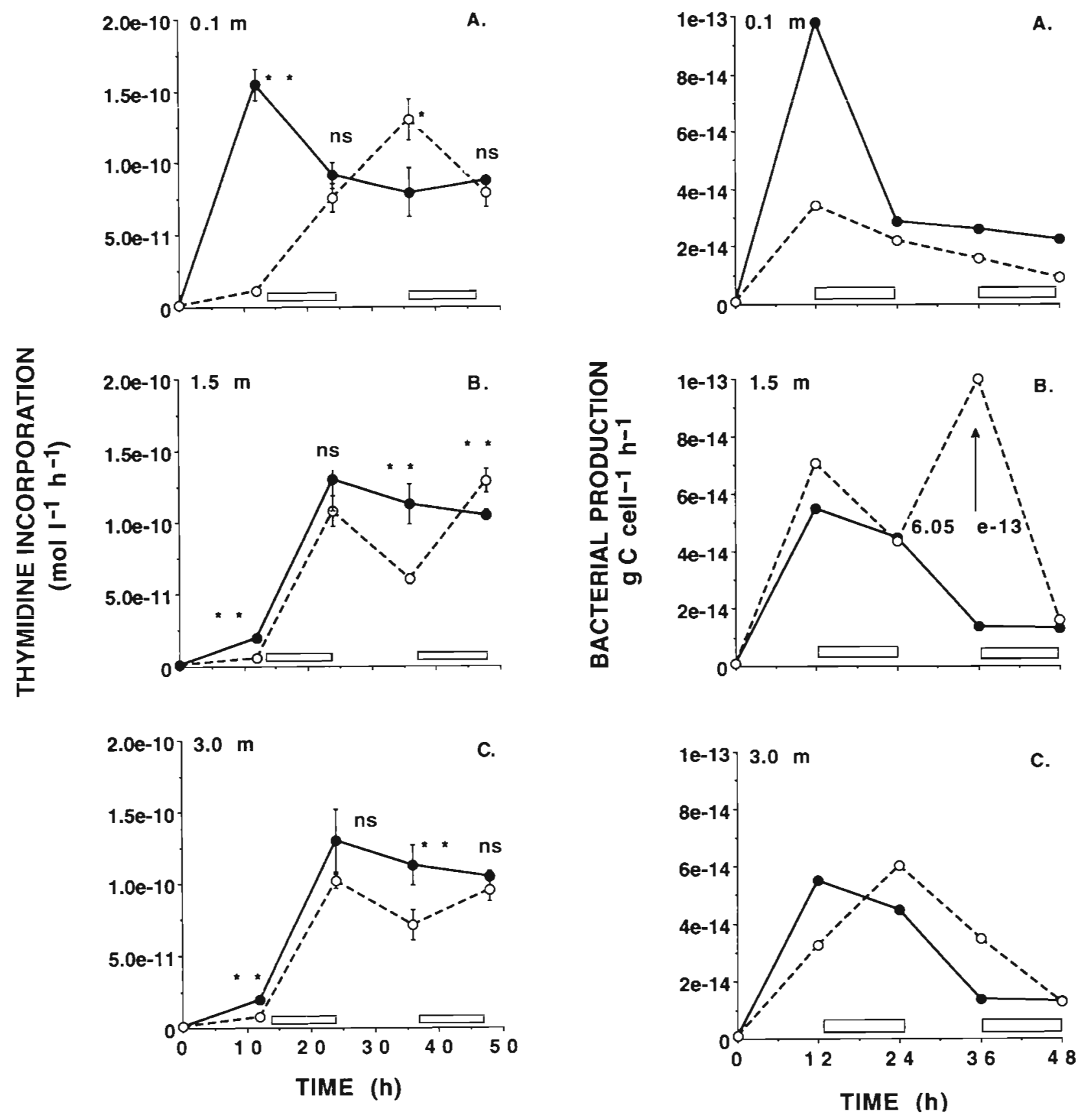

Fig. 4. Time course of bacterial thymidine (TdR) incorporation rates in $0.8 \mu \mathrm{m}$ size-fractionated reef water exposed to in situ solar radiation, May 1 to 3, 1995. (O) Light treatments; (C) dark treatments. Error bars $= \pm 1 \mathrm{SD}$. Bars on $x$-axis approximate periods of darkness Statistical differences between light and dark treatments shown as in Fig. 3

Dark TdR and Leu incorporation rates at dusk of Day 1 were significantly higher in the $0.1 \mathrm{~m}$ deployment than at 1.5 and $3.0 \mathrm{~m}$ (Figs. $3 \& 4$ ). Midday temperatures in the outdoor bath used to incubate the $0.1 \mathrm{~m}$ treatment, however, were as much as $5^{\circ} \mathrm{C}$ higher $\left(29^{\circ} \mathrm{C}\right)$ than those measured on the reef $\left(24^{\circ} \mathrm{C}\right)$. The rapid increase in $\mathrm{TdR}$ and

Leu incorporation rates observed in the $0.1 \mathrm{~m}$ dark treatment during Day 1 may have resulted from temperatureenhanced growth in this treatment relative to reefdeployed bottles during both daylight periods.

Initial cell-specific bacterial production was $1.0 \mathrm{fg} \mathrm{C}$ cell $^{-1} \mathrm{~h}^{-1}$ and generally $<60 \mathrm{fg} \mathrm{C} \mathrm{Cell}^{-1} \mathrm{~h}^{-1}$ over the course of the incubations (Fig. 5). Cell-specific production rates

Fig. 5. Time course of cell-normalized bacterial $\mathrm{C}$ production rates in $0.8 \mu \mathrm{m}$ size-fractionated reef water exposed to in situ solar radiation, May 1 to 3, 1995. (O) Light treatments; (O) dark treatments. Bars on $x$-axis approximate periods of darkness 

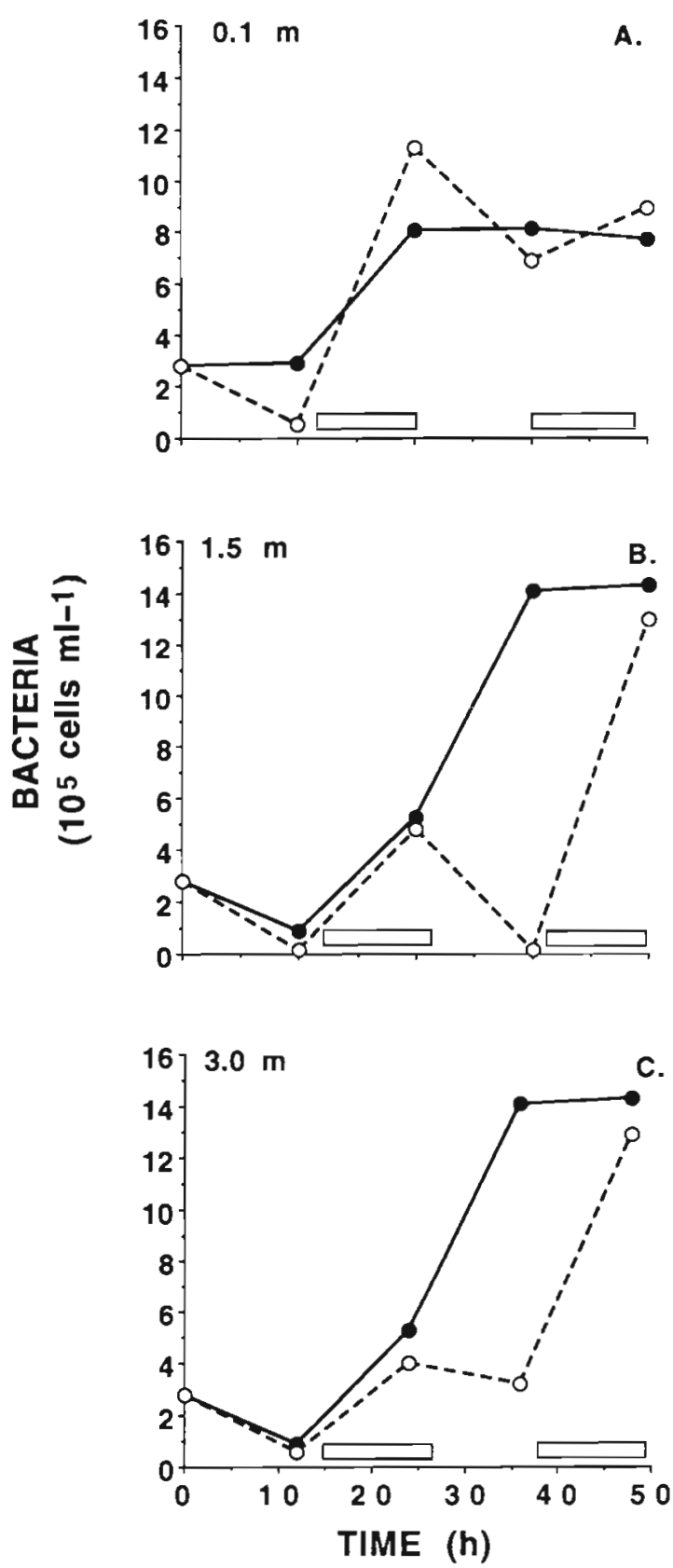

Fig. 6. Time course of bacterial cell concentrations in $0.8 \mu \mathrm{m}$ size-fractionated reef water exposed to in situ levels of solar radiation, May 1 to 3, 1995. (O) Light treatments; (O) dark treatments. Bars on $x$-axis approximate periods of darkness

in dark treatments were highest at dusk of Day 1 and declined thereafter. Cell-specific production rates were higher in the dark compared with light treatments in the $0.1 \mathrm{~m}$ samples, particularly during Day 1 (Fig. 5). With the exception of the $t=36 \mathrm{~h}$ light value, cell-specific production rates in the $1.5 \mathrm{~m}$ samples were similar in both light and dark treatments. As a consequence of the dramatic reduction in cell abundances observed during Day 2 (see below), cell-specific production in the $1.5 \mathrm{~m}$ light treatment at $t=36 \mathrm{~h}$ was several-fold higher than values determined at other time periods.

\section{Bacterial abundances}

Temporal changes in cell concentrations generally corresponded to temporal patterns of Leu and TdR incorporation rates. Cell concentrations in the $0.1 \mathrm{~m}$ dark treatment did not change appreciably during Day 1 (Fig. 6), increased $\sim 4$-fold during the first evening period and remained constant thereafter. Cell concentrations in the $0.1 \mathrm{~m}$ light treatment, however, decreased during both daylight periods and exhibited recovery during the evening hours. In the $1.5 \mathrm{~m}$ dark treatment, cell concentrations exhibited a logistic-type growth curve after an initial lag period (Fig. 6). Both 1.5 and $3.0 \mathrm{~m}$ light treatments also exhibited a lag during Day 1, increases in cell abundances during the first evening period, a decrease during Day 2 and a dramatic recovery during the final evening period.

No autofluorescent cells or DAPI-staining protozoa were observed in any sample over the course of the experimental incubations, indicating that photosynthetic and bacterivorous organisms were not present in significant concentrations in the filtered reef water used for experimental cultures.

\section{Dissolved oxygen consumption}

There were no significant differences $(p=0.20$; Student's $t$-test) in $\mathrm{H}^{14} \mathrm{CO}_{3}^{-}$incorporation between aliquots of $0.8 \mu \mathrm{m}$ filtered reef water incubated in the light and dark, or between either light and dark treatment and the initial $(t=0)$ incorporation rate (Table 2). This comparison suggested that photosynthesis in the filtered reef water used in these experiments was negligible and did not interfere with observed changes in $\mathrm{O}_{2}$ concentrations.

Table 2. Photosynthetic incorporation of ${ }^{14} \mathrm{C}$-bicarbonate in $0.8 \mu \mathrm{m}$ size-fractioned reef water. Initial activity was determined by filtering aliquots of size-fractioned reef water immediately after label addition $(t=0)$. Light and dark samples were filtered and assayed for activity after $6 \mathrm{~h}$ of exposure to sunlight at a depth of $0.1 \mathrm{~m}$

\begin{tabular}{lc} 
Treatment. & $\mathrm{dpm} \pm \mathrm{SO}$ \\
\hline Initial $(t=0)$ & $79 \pm 53$ \\
Light $(t=6 \mathrm{~h})$ & $188 \pm 109$ \\
Dark $(t=6 \mathrm{~h})$ & $119 \pm 40$ \\
\hline
\end{tabular}



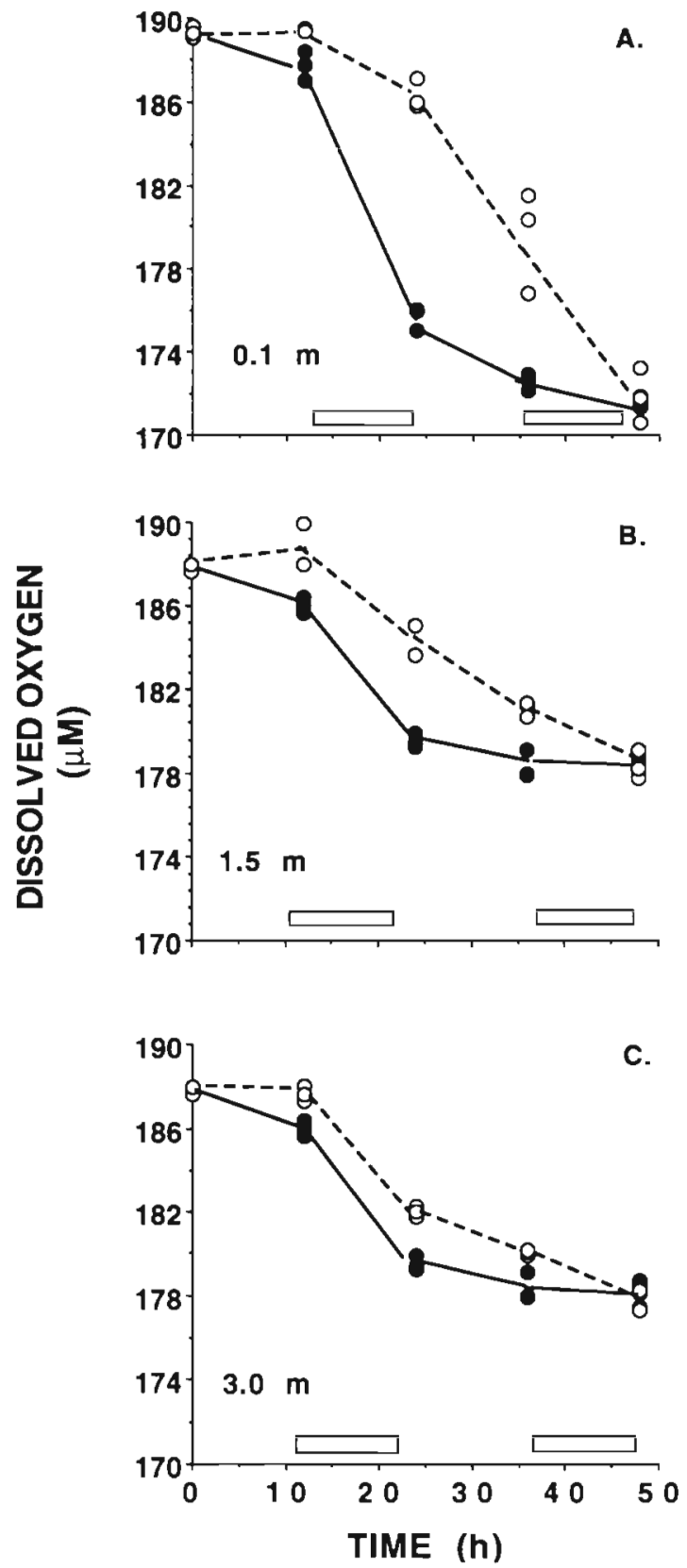

Fig. 7. Time course of bacterial $\mathrm{O}_{2}$ consumption in $0.8 \mu \mathrm{m}$ size-fractionated reef water exposed to in situ levels of solar radiation, May 1 to 3, 1995. Each point represents the $\mathrm{O}_{2}$ concentration of a replicate BOD (biological oxygen demand) bottle. (O) Light treatments; (O) dark treatments. Bars on $x$ axis approximate periods of darkness

Dissolved $\mathrm{O}_{2}$ concentrations in experimental chambers followed temporal patterns, reflecting changes in bacterial growth at all 3 depths (Fig. 7). No significant changes in $\mathrm{O}_{2}$ concentrations were observed in light treatments during Day 1, indicating that light-mediated abiotic $\mathrm{O}_{2}$ consumption (from the photodegradation of dissolved organic matter; Lindell \& Rai 1994) was below the limit of detection and did not interfere with the measurement of bacterial $\mathrm{O}_{2}$ consumption in light treatments at subsequent time points. Differences in $\mathrm{O}_{2}$ concentrations between light and dark treatments over the duration of the incubations were greatest at $0.1 \mathrm{~m}$ and declined with depth. No significant differences between light and dark treatment $\mathrm{O}_{2}$ concentrations were observed at any depth at dawn of Day 3.

No significant bacterial $\mathrm{O}_{2}$ consumption was observed in light treatments during Day 1, although significant rates were measured in dark treatments during this period (Table 3). Light treatment $\mathrm{O}_{2}$ consumption rates were lower than dark treatment rates during the first evening period and increased with depth. In contrast, light treatment $\mathrm{O}_{2}$ consumption rates measured during Day 2 were enhanced relative to dark treatments and decreased with depth.

Cell-specific $\mathrm{O}_{2}$ consumption rates determined during the first evening (Night 1) and second daylight period (Day 2) generally reflected community level $\mathrm{O}_{2}$ consumption trends (Table 4). Light treatment cell-specific $\mathrm{O}_{2}$ consumption rates during the first evening period were lower than dark treatment values and increased with depth. Light treatment cell-specific $\mathrm{O}_{2}$ consumption rates determined during Day 2 were higher than dark treatment values at all depths. Unlike community level $\mathrm{O}_{2}$ consumption rates, the highest rate of cell-specific $\mathrm{O}_{2}$ consumption during Day 2 was observed at $1.5 \mathrm{~m}$. These results suggested that bacterial respiration in light treatments was inhibited during the daylight and evening periods of Day 1 but stimulated relative to dark treat-

Table 3. Reef bacterial community $\mathrm{O}_{2}$ consumption $\left(\mu \mathrm{M} \mathrm{h}^{-1}\right)$ during exposure to solar radiation, May 1 to 2,1995 . ns: not significant $(\mathrm{p}>0.05)$

\begin{tabular}{|lcccccc|}
\hline \multicolumn{2}{|c}{ Depth (m) } & \multicolumn{2}{c}{ Day 1 } & \multicolumn{2}{c|}{ Night 1 } & \multicolumn{2}{c|}{ Day 2 } \\
& Light & Dark & Light & Dark & Light & Dark \\
\hline 0.1 & ns & 0.14 & 0.26 & 1.00 & 0.56 & 0.26 \\
1.5 & ns & 0.14 & 0.42 & 0.54 & 0.29 & 0.10 \\
3.0 & ns & & 0.47 & & 0.16 & \\
\hline
\end{tabular}

Table 4. Cell-specific bacterial $\mathrm{O}_{2}$ consumption (fmol cell ${ }^{-1}$ $\mathrm{h}^{-1}$ ) during the first evening (Night 1) and second day (Day 2) of exposure to solar radiation, May 1 to 2, 1995

\begin{tabular}{|lcccc|}
\hline \multirow{2}{*}{ Depth (m) } & \multicolumn{3}{c}{ Night 1 } & \multicolumn{2}{c|}{ Day 2 } \\
& Light & Dark & Light & Dark \\
\hline 0.1 & 0.45 & 1.83 & 0.61 & 0.32 \\
1.5 & 1.69 & 1.74 & 1.16 & 0.10 \\
3.0 & 2.05 & & 0.44 & \\
\hline
\end{tabular}


ments during Day 2 and that this inhibitory or stimulatory effect was inversely related to depth.

\section{Bacterial growth efficiencies}

With the exception of the $0.1 \mathrm{~m}$ light treatment, community GGE among light and dark treatments were remarkably similar during the first evening period (Table 5). Dark treatment community GGE determined during Day 2 were higher than those measured during the previous evening. In contrast to the evening of Day 1, light treatment community GGE were lower than dark treatment estimates and increased with depth.

\section{DISCUSSION}

\section{Effect of solar radiation on reef bacterial biosynthesis and cell abundances}

Temporal patterns in $\mathrm{TdR}$ and Leu incorporation rates indicated that exposure to solar radiation significantly inhibited the growth of reef bacterioplankton. Because of nutrient enrichments and the absence of photosynthetic and bacterivorous organisms, the temporal variations in bacterial production and respiration were the result of exposure to solar radiation and not a response to diel variations in phytoplankton-derived organic $\mathrm{C}$, bacterivory or the initial availability of $\mathrm{C}, \mathrm{N}$ or $\mathrm{P}$. The responses of the reef bacteria to solar radiation were consistent with previous reports of UVRmediated photoinhibition of bacterial growth (Sieracki \& Sieburth 1986, Herndl et al. 1993, Müller-Niklas et al. 1995) and suggested that biologically effective levels of UVR penetrated to depths equivalent to $75 \%$ of the reef water column.

Sieracki \& Sieburth (1986) reported significant time lags in the growth of marine bacteria exposed to sunlight. The temporal patterns of Leu and TdR incorporation and $\mathrm{O}_{2}$ consumption observed in the present investigation also indicated that exposure to solar radiation induced time lags in reef bacterioplankton biosynthesis and respiration relative to dark-incubated

Table 5. Gross growth efficiencies (\%) of reef bacteria during exposure to solar radiation, May 1 to 2, 1995

\begin{tabular}{|lcccc|}
\hline \multirow{2}{*}{ Depth $(\mathrm{m})$} & \multicolumn{2}{c}{ Night 1 } & \multicolumn{2}{c|}{ Day 2 } \\
& Light & Dark & Light & Dark \\
\hline 0.1 & 81 & 68 & 72 & 88 \\
1.5 & 69 & 69 & 82 & 95 \\
3.0 & 70 & & 90 & \\
\hline
\end{tabular}

samples at all 3 depths. Changes in cell abundances observed in both light and dark treatments during Day 1, however, indicated that the initial lag period in cell abundance curves could not be attributed solely to photoinhibition. The decreases in cell abundances observed at all 3 depths during Day 2 further suggested that photoinduced cell lysis occurred during this period which initiated a secondary lag in light treatment cell production. A similar reduction in light treatment cell concentrations has been reported by Müller-Niklas et al. (1995). The diurnal decreases in light treatment cell abundances observed in the present investigation and by Müller-Niklas et al. (1995) suggested that photoinduced cell lysis, in addition to grazing and virus-induced lysis (Fuhrman \& Noble 1995), may contribute to bacterial mortality in aquatic habitats exposed to solar radiation.

Jeffrey et al. (1996) reported that bacterioplankton in surface waters of the central Gulf of Mexico exhibited nighttime repair of DNA damage after diurnal exposure to sunlight. Müller-Niklas et al. (1995) and Guerrero \& Jones (1996) also reported that heterotrophic and nitrifying bacteria exhibited dark recovery of $\mathrm{TdR}$ incorporation and $\mathrm{N}$ oxidation rates, respectively, following exposure to sunlight. The nighttime increases in light treatment biosynthesis, cell abundances and $\mathrm{O}_{2}$ consumption observed in the present study indicated that reef heterotrophic bacterioplankton were also capable of recovery in growth and metabolism following diurnal exposure to sunlight.

Trends in Leu and TdR incorporation and $\mathrm{O}_{2}$ consumption with depth indicated that photoinhibition of bacterial growth and respiration and subsequent nighttime recovery were dependent on the degree of exposure to UVR during the day. Photoinhibition of bacterial production was greatest at the surface during both daylight periods and corresponded to the trend in downwelling UVR. Subsequent recovery of bacterial respiration during the first evening period was lowest at the surface and increased with depth, indicating that night recovery of bacterial respiration was inhibited by higher doses of UVR received by the surface incubated samples during the previous daylight period. The trend of increasing growth efficiencies with increasing depth observed during Day 2 of the experiment was also consistent with greater exposure of surface incubated samples to UVR and attenuation of UVR with depth.

The decrease in photoinhibition of bacterial biosynthesis observed between Day 1 and 2 suggested that photoacclimation to ambient light regimes occurred during the second day of exposure. With the exception of photolyase and RecA DNA repair mechanisms (Friedberg et al. 1995), bacterial physiological adaptations to the deleterious effects of UVR are poorly understood. Thomson et al. (1980) reported an increase 
in the percentage of pigmented cells during exposure of estuarine bacteria to artificial UVR. Bailey et al. (1983) and Herndl et al. (1993), however, reported that bacteria collected from surface and decper waters exhibited similar responses to UVR exposure, suggesting that surface dwelling bacteria possessed no special photoadaptation to that environment. The native reef bacteria collected for experimentation in the present study exhibited dramatic initial photoinhibition of growth and respiration to in situ light regimes, indicating that they also possessed little initial photoadaptation to this environment and that their survival and activity were dependent on recovery during the night. The diel variations in percent photoinhibition, cell concentrations, and respiration further suggested that the initial bacterioplankton community exhibited either selection for photoresistant cells or induction of physiological adaptations (or both) in response to exposure to sunlight. Diurnal exposure to sunlight may thus act as a selection agent that may favor the development of reef bacterioplankton communities adapted to stressful light regimes.

The decrease in bacterial growth efficiencies observed in light treatments during Day 2 of the present investigation indicated that light-induced stress may result in a reallocation of physiological energy flow from biosynthesis and cell division to maintenance, repair and respiration. The increase in bacterial $\mathrm{O}_{2}$ consumption observed in light treatments relative to dark treatments during Day 2 further indicated an increase in substrate respiration rates in response to light stress. Thomson et al. (1980) reported a similar increase in substrate respiration rates in cultures of estuarine bacteria exposed to artificial UVR and found that the increase in substrate respiration in response to UVR was dose-dependent. Hooper \& Terry (1974) further reported reduced photoinhibition of $\mathrm{NH}_{4}{ }^{+}$-oxidizing bacteria where high rates of $\mathrm{NH}_{4}{ }^{+}$oxidation were observed. The above suggested that exposure of bacteria to UVR results in the induction of an energetically expensive physiological response(s) that subsequently imposes greater substrate requirements for cellular maintenance and growth. If this generalization is valid, these observations also suggest that substrate availability may influence the ability of bacterioplankton to respond to light stress.

\section{Effect of solar radiation on bacterial production estimates and growth efficiencies}

Enhanced $\mathrm{O}_{2}$ consumption and reduced Leu incorporation rates observed in light treatments during Day 2 of the experiment indicated that light exposure influenced bacterial growth efficiencies. The growth efficiencies presented herein were not intended as measures of in situ values, but rather to elucidate the relative effect of solar radiation on bacterial growth and metabolism at different depths in the reef water column. These estimates were derived from native bacterial assemblages responding to nutrient enrichment and were several-fold higher than bacterial GGE reported from the Gulf of Mexico (mean <20\%; Benner et al. 1992, Coffin et al. 1993, Biddanda et al. 1994, Pomeroy et al. 1995). Our estimates of GGE, however, were similar to values measured in nutrient-replete laboratory cultures (Payne \& Wiebe 1978, Goldman et al. 1987). Furthermore, these values were dependent on assumptions for carbon conversion of Leu incorporation and oxygen consumption rates that may not have been appropriate for the experimental conditions. Given these caveats, however, our data strongly suggested that light exposure reduced light treatment bacterial growth efficiencies relative to dark treatments during Day 2 of the experiment.

Measurements of bacterioplankton production based on Leu and TdR incorporation and bacterial $\mathrm{O}_{2}$ consumption are commonly conducted in the dark to control for the potential effects of photosynthesis (e.g. Bell 1993). Müller-Niklas et al. (1995) have suggested that measurements of bacterial production in the dark may overestimate bacterial production in euphotic marine environments. The results of the present investigation also suggested that measurements of bacterioplankton production and respiration based on lengthy dark incubations may, in some instances, significantly overestimate in situ bacterial production and respiration rates in euphotic marine environments. Incubation times commonly employed during Leu and TdR incorporation measurements, however, are short (usually $<1 \mathrm{~h}$ ), but can extend up to $10 \mathrm{~h}$ depending on habitat or application (Kirchman 1993). In contrast, incubation times needed to determine significant rates of bacterial and community respiration (e.g. the present study) are generally several-fold longer than those to determine bacterial production by Leu or TdR incorporation. Light exposure during short-term Leu and TdR incorporation and longerterm bacterial respiration measurements may thus influence estimates of bacterial growth efficiencies in euphotic marine habitats.

\section{Solar radiation and bacterioplankton metabolism in shallow marine habitats}

The results of the present investigation and previous studies (Thomson et al. 1980, Bailey et al. 1983, Sieracki \& Sieburth 1986, Herndl et al. 1993, Müller-Niklas et al. 1995) indicate that solar radiation can directly 
and adversely influence marine bacterioplankton production, respiration and growth efficiencies over diel cycles. Other studies (Burney et al. 1982, Riemann \& Søndergaard 1984, Riemann et al. 1984, Fuhrman et al. 1985, Coffin et al. 1993), however, indicate that additional factors such as diel variations in the photosynthetic production of organic substrates and bacterivory also exert a powerful influence on bacterioplankton diel activity which may mask the deleterious effect of solar radiation. The relative importance of trophic interactions and photoinhibition to bacterial metabolism in shallow marine habitats may thus vary with the intensity of exposure to biologically effective UVR, the degree to which the bacterial community is adapted to local light regimes, and the strength of trophic linkages between phytoplankton and bacterivores and the bacterioplankton community.

Phytoplankton ecologists have long recognized the importance of vertical mixing to the response of phytoplankton exposed to varying light levels in the mixed layer of the water column (Sverdrup 1953). Jeffrey et al. (1996) reported enhanced bacterial DNA photodamage during periods of low wind stress and mixing in the central Gulf of Mexico, suggesting that vertical mixing may similarly influence the exposure and subsequent effect of solar radiation on bacterioplankton activity. In pelagic systems, the net effect of solar radiation on bacterioplankton within an actively mixed water column would be a function of light exposure and photoinhibition in near-surface waters and light attenuation and physiological recovery in deeper waters (Fig. 8). If these latter assumptions are valid, there may exist under any particular set of

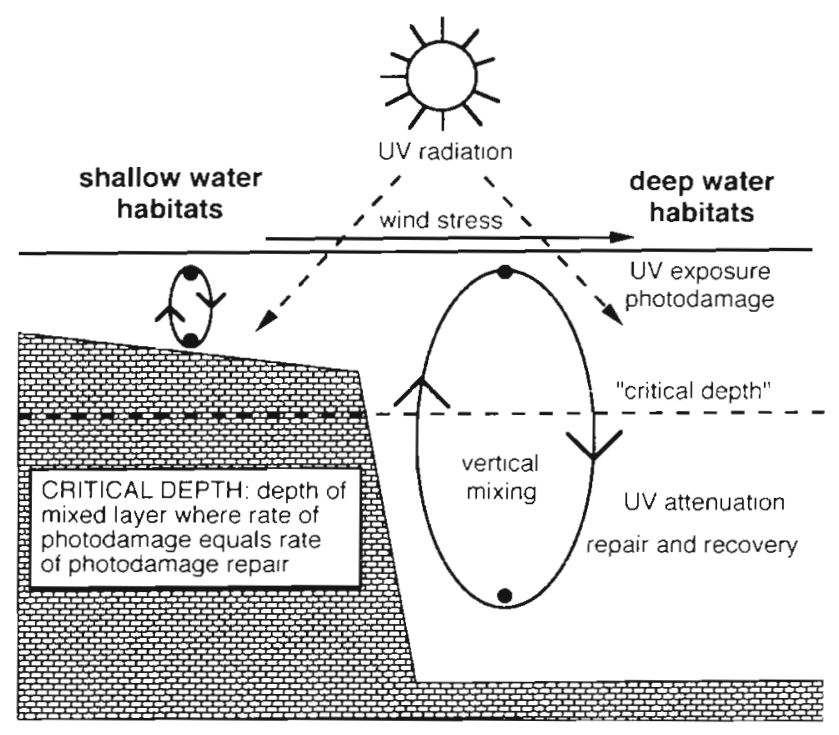

Fig. 8. Influence of mixing on exposure of bacterioplankton to solar radiation in shallow- and deep-water marine habitats hydrodynamic and light conditions a 'critical depth' (sensu Sverdrup 1953), similar to that applied to water column photosynthesis, where light exposure determines whether a net negative influence on bacterial community production and metabolism may occur. The depth of the water column in relation to this critical depth would be an important factor influencing bacterioplankton production and respiration. In coral reefs and other shallow water habitats where this hypothetical critical depth may be located at depths greater than the total water column, the influence of light on these systems may be fundamentally different than in deep-water communities where vertical mixing may lessen the negative impact of exposure to solar radiation.

The residence time of bacterioplankton in shallow euphotic habitats, where light may exert selective pressure for photoadapted cells, may also influence bacterioplankton community structure as well as metabolism. In hydrographically open systems where advection results in the rapid transport of cells through shallow waters exposed to intense solar radiation, bacterial residence times may be too short for effective photoacclimation to occur. Under those conditions, solar radiation may result in general photoinhibition of bacterial activity. In hydrographically isolated shallowwater habitats where bacterial residence times are lengthy, selection for photoadapted cells may result in changes in bacterial community structure that may lessen the deleterious impact of light on bacterioplankton metabolism. In the reef studied in the present investigation, where biologically effective levels of solar radiation penetrated throughout much of the water column and where residence times of planktonic bacteria on the reef may be brief, vertical mixing may not ameliorate the deleterious effects of solar radiation on bacterioplankton abundances and activity. In this reef system, and in similar shallow non-turbid marine habitats, the effect of UVR on bacterioplankton growth and metabolism may thus be greater than in pelagic marine environments exposed to similar levels of solar radiation.

Acknowledgements. This work was supported by the National Atmospheric and Oceanographic Administration's National Undersea Research Center at the University of North Carolina at Wilmington NOAA contract UNCW9518, U.S. Environmental Protection Agency Cooperative Agreement CR822020-01 through the Gulf Ecology Division Laboratory in Gulf Breeze, FL, to W.H.J., and a National Research Council Postdoctoral Fellowship to J.D.P. We thank J. Mitchell and the staff of the National Undersea Research Laboratory for assistance in field sampling, and R. Devereux and S. Howard for technical review of the manuscript. The use of any product cited in this report does not imply its official endorsement by the U.S. Environmental Protection Agency. 


\section{LITERATURE CITED}

Azam F, Fenchel T, Field JG, Gray JS, Meyer-Reil LA, Thingstad $F$ (1983) The ecological role of water-column microbes in the sea. Mar Ecol Prog Ser 10:257-263

Bailey CA, Nehof RA, Tabor PS (1983) Inhibitory effect of solar radiation on amino acid uptake in Chesapeake Bay bacteria. Appl Environ Microbiol 46:44-49

Bell RT (1993) Estimating production of heterotrophic bacterioplankton via incorporation of tritiated thymidine. In: Kemp PF, Sherr BF, Sherr EV, Cole JJ (eds) Handbook of methods in aquatic microbiology. Lewis Publishers, Boca Raton, p 495-503

Benner R, Chin-Leo G, Gardner W, Eadie B, Cotner J (1992) The fates and effects of riverine and shelf-derived DOM on Mississippi River plume/Gulf processes. Proceedings of the NOAA Nutrient Enhanced Coastal Ocean Productivity Synthesis Workshop, Cocodrie, LA, October, 1991. Texas Sea Grant Publications TAMU-SG-92-109, p 84-94

Biddanda B, Opsahl S, Benner R (1994) Plankton respiration and carbon flux through bacterioplankton on the Louisiana shelf. Limnol Oceanogr 39:1259-1275

Burney CM, Davis PG, Johnson KM. Sieburth JMCN (1982) Diel relationships of microbial trophic groups and in situ dissolved carbohydrate dynamics in the Caribbean Sea. Mar Biol 67:311-322

Chin-Leo G, Kirchman D (1988) Estimating bacterial production in marine waters from the simultaneous incorporation of thymidine and leucine. Appl Environ Microbiol 54: $1934-1939$

Cho BC, Azam F (1990) Biogeochemical significance of bacterial biomass in the ocean's euphotic zone. Mar Ecol Prog Ser 63:253-259

Coffin RB, Connolly JP, Harris PS (1993) Availability of dissolved organic carbon to bacterioplankton examined by oxygen utilization. Mar Ecol Prog Ser 101:9-22

Cole JJ, Findlay S, Pace ML (1988) Bacterial production in fresh and salt water ecosystems: a cross-system overview. Mar Ecol Prog Ser 43:1-10

Cooper WJ, Zika RG, Petnase RG, Fisher AM (1989) Sunlight induced photochemistry of humic substances in natural waters: major reactive species. Adv Chem Ser 219: $333-362$

Fleishmann EM (1989) The measurements of penetration of ultraviolet radiation into tropical marine water. Limnol Oceanogr 34:1623-1629

Friedberg EC, Walker GC, Siede W (1995) DNA repair and mutagenesis American Society for Microbiology Press, Washington, DC

Fuhrman JA, Eppley RW, Hagström $\AA$, Azam F (1985) Diel variations in bacterioplankton, phytoplankton, and related parameters in the Southern California Bight. Mar Ecol Prog Ser 27:9-20

Fuhrman JA, Noble RT (1995) Viruses and protists cause similar bacterial mortality in coastal seawater. Limnol Oceanogr 40:1236-1242

Granéli W, Granéli E (1991) Automatic potentiometric determination of dissolved oxygen. Mar Biol 108:341-348

Goldman JC, Caron DA, Dennet MR (1987) Regulation of gross growth efficiency and ammonium regeneration in bacteria by substrate $\mathrm{C}: \mathrm{N}$ ratio. Limnol Oceanogr 32 : $1239-1252$

Guerrero MA, Jones RD (1996) Photoinhibition of marine nitrifying bacteria. II. Dark recovery after monochromatic or polychromatic irradiation. Mar Ecol Prog Ser 141: $193-198$
Häder DP, Worrest RC, Kumar HD, Smith RC (1995) Effects of increased solar ultraviolet radiation on aquatic ecosystems. Ambio 24:174-180

Herndl GJ, Müller-Niklas G, Frick J (1993) Major role of ultraviolet-B in controlling bacterioplankton growth in the surface layer of the ocean. Nature 361:717-719

Hooper AB, Terry KR (1974) Photoinactivation of ammonium oxidation in Nitrosomonas. J Bacteriol 119:899-906

Horrigan SG, Springer AL (1990) Oceanic and estuarine ammonium oxidation: effects of light. Limnol Oceanogr 35 $479-482$

Jeffrey WH, Pledger RJ, Aas P, Hager S, Coffin RB, Von Haven R, Mitchell DL (1996) Diel and depth profiles of DNA photodamage in bacterioplankton exposed to ambient solar ultraviolet radiation. Mar Ecol Prog Ser 137: 283-291

Kampa EM (1976) Photoenvironment and vertical migrations of mesopelagic marine animal communities. In: De Coursey PM (ed) Biological rhythms in the marine environment. Belle W Baruch Library in Marine Science No. 4. University of South Carolina Press, Columbia, p 257-272

Kirchman DL (1993) Leucine incorporation as a measure of bacterial biomass production by heterotrophic bacteria In: Kemp PF, Sherr BF, Sherr EV, Cole JJ (eds) Handbook of methods in aquatic microbiology. Lewis Publishers, Boca Raton, p 509-512

Kirk JTO (1994) Light and photosynthesis in aquatic ecosystems, 2nd edn. Cambridge Press, Cambridge

Lindell MJ, Granéli W, Tranvik LJ (1995) Enhanced bacterial growth in response to photochemical transformation of dissolved organic matter. Limnol Oceanogr 40:195-199

Lindell MJ, Granéli W, Tranvik LJ (1996) Effects of sunlight on bacterial growth in lakes of different humic content Aquat Microb Ecol 11:135-141

Lindell MJ, Rai H (1994) Photochemical oxygen consumption in humic waters. Arch Hydrobiol Beih Ergebn Limnol 43: $143-155$

Lipshultz FL, Wofsy SC, Fox LE (1985) Effects of light and nutrients on rates of ammonium transformation in a eutrophic river. Mar Chem 16:329-341

Müller-Niklas G, Heissenberger A, Puškarić S, Herndl GJ (1995) Ultraviolet-B radiation and bacterial metabolism in coastal waters. Aquat Microb Ecol 9:111-116

Nishino SF (1986) Direct acridine orange counting of bacteria preserved with acid Lugol's solution. Appl Environ Microbiol 52:602-604

Olsen RJ (1981) Differential photoinhibition of marine nitrifying bacteria: a possible mechanism for the formation of the primary nitrite maximum. J Mar Res 39:227-238

Oudot C, Gerard R, Morin P, Gningue I (1988) Precise shipboard determination of dissolved oxygen (Winkler procedure) for productivity studies with a commercial system. Limnol Oceanogr 33:146-150

Owens NPJ (1986) Estuarine nitrification: a naturally occurring fluidized bed reaction. Estuar Coast Shelf Sci 22: $31-44$

Payne WJ, Wiebe WJ (1978) Growth yield and efficiency in chemosynthetic microorganisms. Annu Rev Microbiol 32 155-183

Pomeroy LR, Sheldon JE, Sheldon WM Jr, Peters F (1995) Limits to growth and respiration of bacterioplankton in the Gulf of Mexico. Mar Ecol Prog Ser 117:259-268

Porter KG, Feig Y (1980) The use of DAPI for identifying and counting aquatic microflora. Limnol Oceanogr 25:943-948

Riemann B, Nielsen $P$, Jeppesen M, Marcussen B, Fuhrman JA (1984) Diel changes in bacterial biomass and growth rates in coastal environments, determined by means of 
thymidine incorporation into DNA, frequency of dividing cells (FDC), and microautoradiography. Mar Ecol Prog Ser $17: 227-235$

Riemann B, Sondergaard M (1984) Measurements of diel rates of bacterial secondary production in aquatic environments. Appl Environ Microbiol 47:632-638

Sieracki ME, Sieburth JMcN (1986) Sunlight-induced growth and delay of planktonic marine bacteria in filtered seawater. Mar Ecol Prog Ser 33:19-27

Simon M, Azam F (1989) Protein content and protein synthesis rates of planktonic marine bacteria. Mar Ecol Prog Ser 51:201-213

Smith RC, Baker KS (1979) Penetration of UV-B and biologically effective dose rates in natural waters. Photochem Photobiol 29:311-323

Sommaruga R, Oberleiter A, Psenner R (1996) Effect of UV radiation on the bacterivory of a heterotrophic nanoflagellate. Appl Environ Microbiol 62:4395-4400

Stolarski R, Bojkov R, Bishop L, Zerefos C, Staehelin J, Zawondy $\mathrm{J}$ (1992) Measured trends in stratospheric ozone. Science 256:342-349

Editorial responsibility: David Karl, Honolulu, Hawaii, USA
Thomson BE, van Dyke H, Worrest RC (1980) Impact of UV-B radiation 290-320 nanometers upon estuarine bacteria. Oecologia 47:56-60

Sverdrup HU (1953) On conditions for the vernal blooming of phytoplankton. J Cons Explor Mer 18:287-295

Vanzella A, Guerrero MA, Jones RD (1989) Effect of CO and light on ammonium and nitrite oxidation by chemolithotrophic bacteria. Mar Ecol Prog Ser 57:69-76

Ward BB (1985) Light and substrate concentration relationships with marine ammonium assimilation and oxidation rates. Mar Chem 16:301-316

Wetzel RG, Hatcher PG, Bianchi TS (1995) Natural photolysis by ultraviolet irradiance of recalcitrant dissolved organic matter to simple substrates for rapid bacterial metabolism. Limnol Oceanogr 40:1369-1380

Wommack KE, Hill R, Muller TA, Colwell RR (1996) Effects of sunlight on bacteriophage viability and structure. Appl Environ Microbiol 62:1336-1341

Yoshioka T, Saijo Y (1985) Photoinhibition and recovery of $\mathrm{NH}_{4}{ }^{+}$-oxidizing bacteria and $\mathrm{NO}_{2}^{-}$-oxidizing bacteria. J Gen Appl Microbiol, Tokyo 39:151-166

Submitted: May 5, 1997; Accepted: September 16, 1997 Proofs received from author(s): January 16, 1998 


\section{Erratum}

Influence of light on bacterioplankton production and respiration in a subtropical coral reef

J. D. Pakulski, P. Aas, W. Jeffrey, M. Lyons, L. G. van Waasbergen, D. Mitchell, R. Coffin Aquat Microb Ecol 14: 137-148, 1998

- One of the author names was misspelled as L. Von Waasenbergen. The correct name is L. G. van Waasbergen. 